
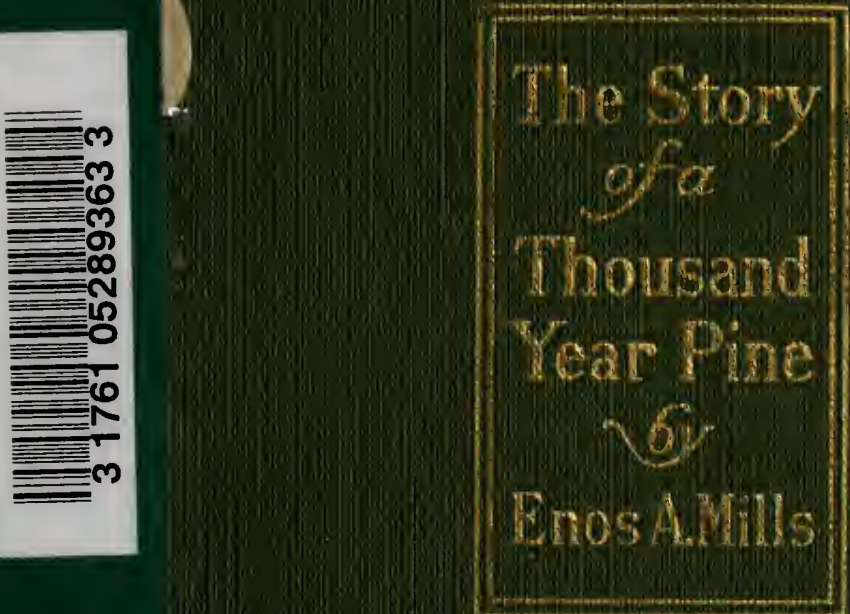

QK 494

5

P66N5 


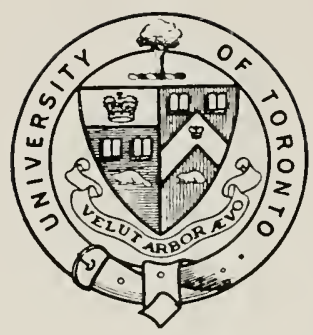

Presented to the

UNIVERSITY OF TORONTO

LIBRARY

by the

ONTARIO LEGISLATIVE

LIBRARY

1980 


Digitized by the Internet Archive in 2008 with funding from Microsoft Corporation 


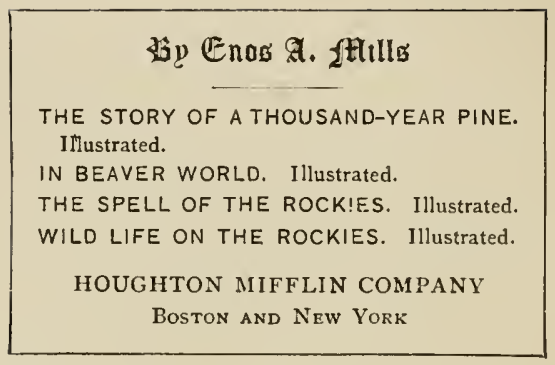




\section{THE STORY OF A THOUSAND-YEAR PINE}

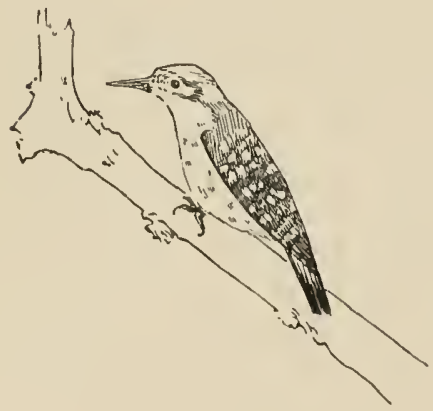






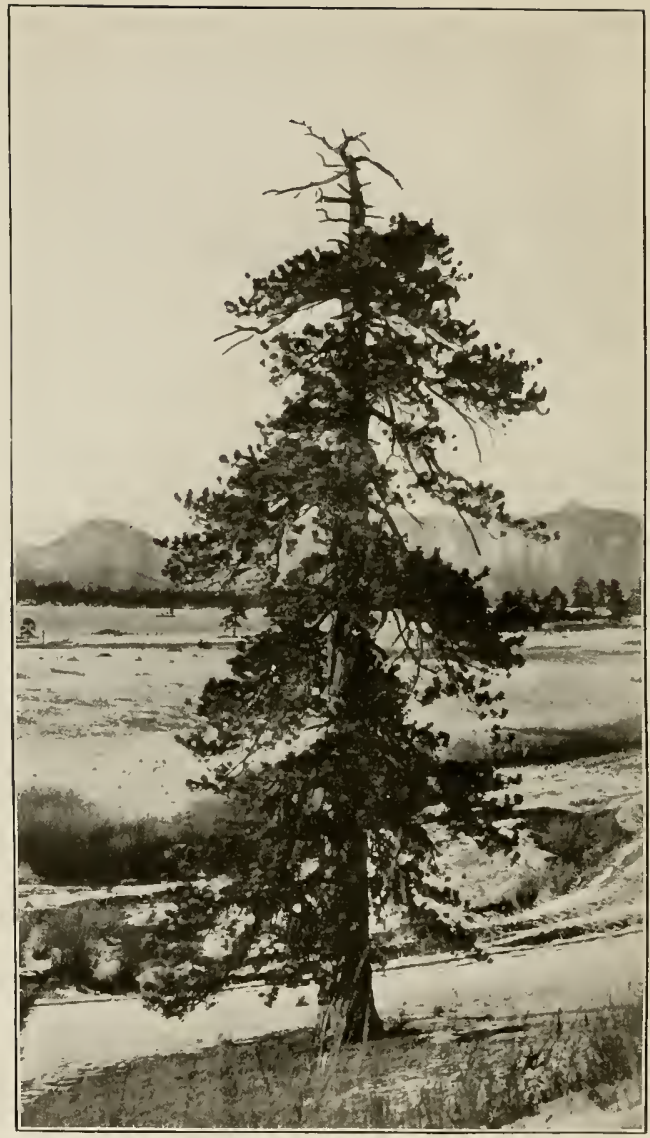


COPYRIGHT, IgO9 AND I9I, BY ENOS A. MILLS

ALL RIGHTS RESERVED

$$
\begin{gathered}
\text { PIAP } \\
1
\end{gathered}
$$




\section{THE STORY OF A THOUSAND-YEAR PINE}

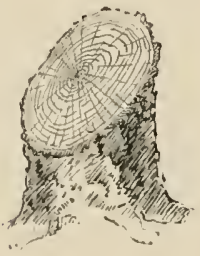





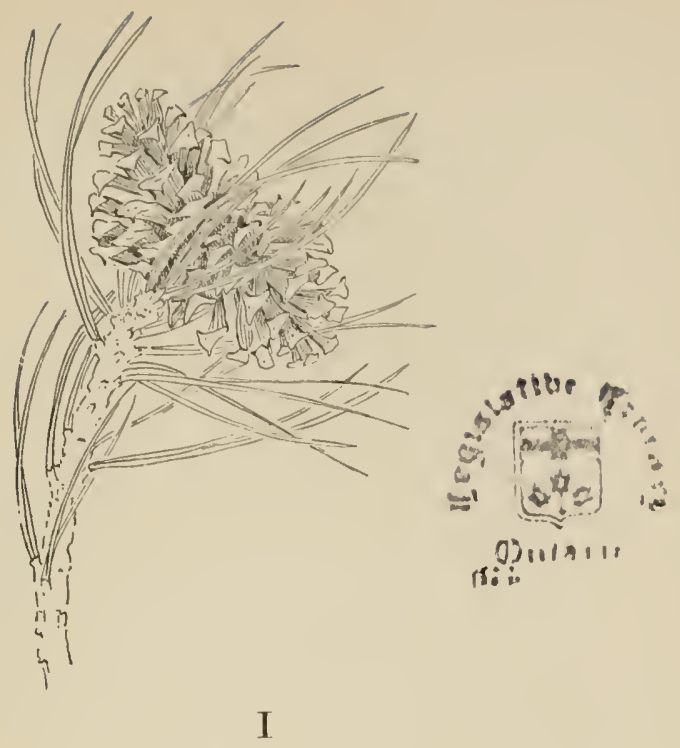

The peculiar charm and fascination that trees exert over many people I had always felt from childhood, but it was that great nature-lover, John Muir, who first showed me how and where to learn their language. Few trees, however, ever held for me such an attraction as did a gigantic and 


\section{A THOUSAND-YEAR PINE}

venerable yellow pine which I discovered one autumn day several years ago while exploring the southern Rockies. It grew within sight of the Cliff-Dwellers' Mesa Verde, which stands at the corner of four States, and as I came upon it one evening just as the sun was setting over that mysterious tableland, its character and heroic proportions made an impression upon me that I shall never forget, and which familiar acquaintance only served to deepen while it yet lived and before the axeman came. Many a time I returned to build my camp-fire by it and have a day or a night in its solitary and noble company. I learned afterwards that it had been given the name "Old Pine," and it certainly had an impressiveness 


\section{A THOUSAND-YEAR PINE}

quite compatible with the age and dignity which go with a thousand years of life.

When, one day, the sawmill-man at Mancos wrote, "Come, we are about to $\log$ your old pine," I started at once, regretting that a thing which seemed to me so human, as well as so noble, must be killed.

I went with the axemen who were to cut the old pine down. A grand and impressive tree he was. Never have I seen so much individuality, so much character, in a tree. Although lightning had given him a bald crown, he was still a healthy giant, and was waving evergreen banners more than one hundred and fifteen feet above the earth. His massive trunk, eight feet in diameter at the level of my breast,

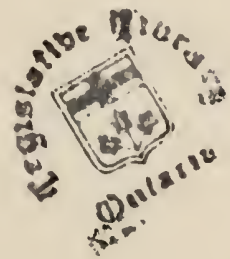




\section{A THOUSAND-YEAR PINE}

was covered with a thick, rough, golden-brown bark which was broken into irregular plates. Several of his arms were bent and broken. Altogether, he presented a timeworn but heroic appearance.

It is almost a marvel that trees should live to become the oldest of living things. Fastened in one place, their struggle is incessant and severe. From the moment a baby tree is born — from the instant it casts its tiny shadow upon the ground - until death, it is in danger from insects and animals. It cannot move to avoid danger. It cannot run away to escape enemies. Fixed in one spot, almost helpless, it must endure flood and drought, fire and storm, insects and earthquakes, or die. 


\section{A 'IHOUSAND-YEAR PINE}

Trees, like people, struggle for existence, and an aged tree, like an aged person, has not only a striking appearance, but an interesting biography. I have read the autobiographies of many century-old trees, and have found their life-stories strange and impressive. The yearly growth, or annual ring of wood with which trees envelop themselves, is embossed with so many of their experiences that this annual ring of growth literally forms an autobiographic diary of the tree's life.

I wanted to read Old Pine's autobiography. A veteran pine that had stood on the southern Rockies and struggled and triumphed through the changing seasons of hundreds of years must contain a rare life-story. From 


\section{A THOUSAND-YEAR PINE}

his stand between the Mesa and the pine-plumed mountain, he had seen the panorama of the seasons and many a strange pageant; he had beheld what scenes of animal and human strife, what storms and convulsions of nature! Many a wondrous secret he had locked within his tree soul. Yet, although he had not recorded what he had seen, I knew that he had kept a fairly accurate diary of his own personal experience. This I knew the saw would reveal, and this I had determined to see.

Nature matures a million conifer seeds for each one she chooses for growth, so we can only speculate as to the selection of the seed from which sprung this storied pine. It may be that the cone in which it matured was 


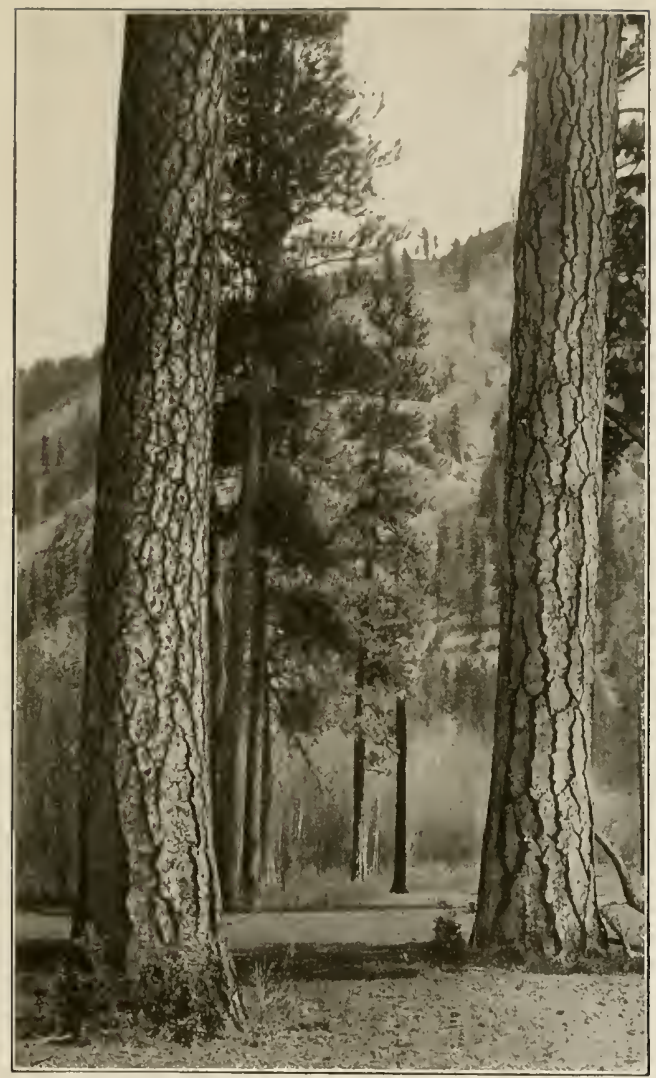

SOME UF "OLD PINE'S" NEIMHBORS

(IVestern Tellow Pines) 



\section{A THOUSAND-YEAR PINE}

crushed into the earth by the hoof of a passing deer. It may have been hidden by a jay; or, as is more likely, the tree may have grown from one of the meaten cones which a squirrel had buried for winter food. Frémont squirrels are the principal murserymen for all the Western pineries. Each autumm they harvest a heavy percentage of the cone crop and bury it for winter. The seeds in the uneaten cones germinate, and each year countless thousands of conifers grow from the seeds planted by these squirrels. It may be that the seed from which Old Pine burst had been planted by an ancient ancestor of the protesting Frémont squirrel whom we found that day in apparent possession of the premises; or this seed may have been 


\section{A THOUSAND-YEAR PINE}

in a cone which simply bounded or

blew into a hole, where the seed found sufficient mould and moisture to give it a start in life.

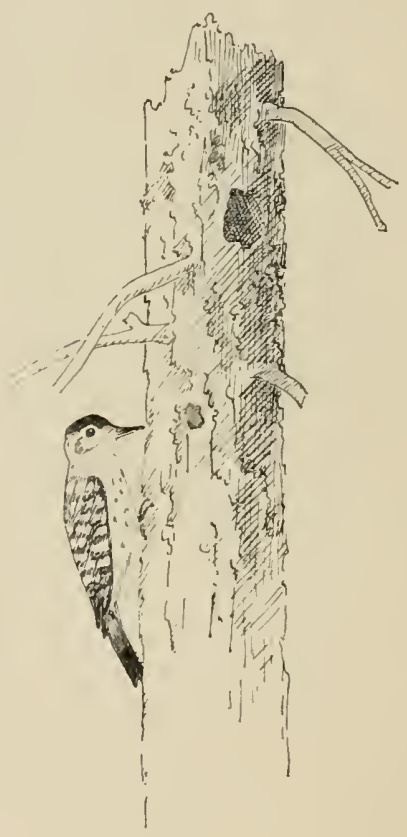




\section{II}

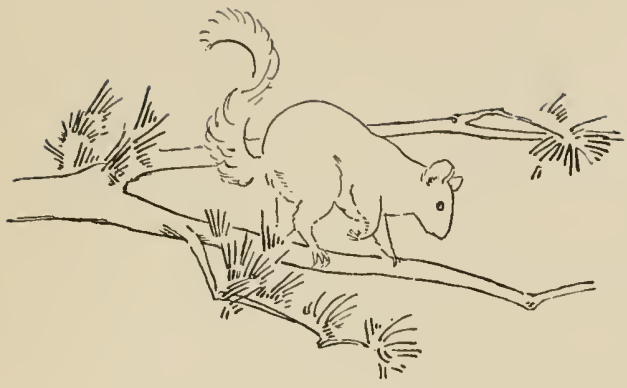





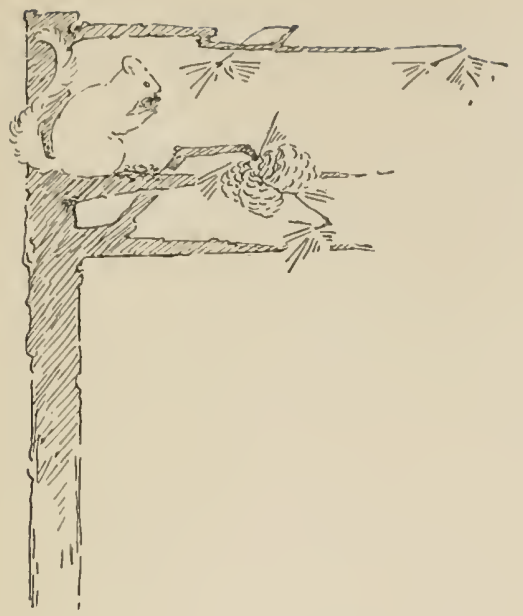

\section{II}

Two loggers swung their axes: at the first blow a Frémont squirrel came out of a hole at the base of a dead limb near the top of the tree and made an aggressive claim of ownership, setting up a vociferous protest against the cutting. As his voice was unheeded, he came scolding down the tree, 


\section{A THOUSAND-YEAR PINE}

jumped off one of the lower limbs, and took refuge in a young pine that stood near by. From time to time he came out on the top of the limb nearest to us, and, with a wry face, fierce whiskers, and violent gestures, directed a torrent of abuse at the axemen who were delivering death-blows to Old Pine.

The old pine's enormous weight caused him to fall heavily, and he came to earth with tremendous force and struck on an elbow of one of his stocky arms. The force of the fall not only broke the trunk in two, but badly shattered it. The damage to the $\log$ was so general that the sawmill-man said it would not pay to saw it into lumber and that it could rot on the spot. 


\section{A THOUSAND-YEAR PINE}

I had come a long distance for the express purpose of deciphering Old Pine's diary as the scroll of his life should be laid open in the sawmill. The abandonment of the shattercd form compelled the adoption of another way of getting at his story. Receiving permission to do as I pleased with his remains, I at once began to cut and split both the trunk and the limbs, and to transcribe their strange records. Day after day I worked. I dug up the roots and thoroughly dissected them, and with the aid of a magnifier I studied the trunk, the roots, and the limbs.

I carefully examined the base of his stump, and in it I found ten hundred and forty-seven rings of growth! He had lived through a thousand and 


\section{A THOUSAND-YEAR PINE}

forty-seven memorable years. As he was cut down in 1903, his birth probably occurred in 856 .

In looking over the rings of growth, I found that a few of them were much thicker than the others; and these thick rings, or coats of wood, tell of favorable seasons. There were also a few extremely thin rings of growth. In places two and even three of these were together. These were the results of unfavorable seasons, - of drought or cold. 'The rings of trees also show healed wounds, and tell of burns, bites, and bruises, of torn bark and broken arms. Old Pine not only received injuries in his early years, but from time to time throughout his life. The somewhat kinked condition of several of the rings of growth, beginning with 


\section{A TIOUSAND-YEAR PINE}

the twentieth, shows that at the age of twenty he sustained an injury which resulted in a severe curvature of the spine, and that for some years he was somewhat stooped. I was unable to make out from his diary whether this injury was the result of a tree or some object falling upon him and pinning him down, or whether his back had been overweighted and bent by wet, clinging snow. As I could find no sears or bruises, I think that snow must have been the cause of the injury. However, after a few years he straightened up with youthful vitality and seemed to outgrow and forget the experience.

A century of tranquil life followed, and during these years the rapid growth tells of good seasons as well as 


\section{A THOUSAND-YEAR PINE}

good soil. This rapid growth also shows that there could not have been any crowding neighbors to share the sun and the soil. The tree had grown evenly in all quarters, and the pith of the tree was in the center. But had one tree grown close, on that quarter the old pine would have grown slower than on the others and have been thimner, and the pith would thus have been away from the tree's center.

When the old pine was just completing his one hundred and thirtyfifth ring of growth, he met with an accident which $I$ can account for only by assuming that a large tree that grew several yards away blew over, and in falling, stabbed him in the side with two dead limbs. His bark was broken and torn, but this healed in due time. 


\section{A TIIOUSAND-JEAR PINE}

Short sections of the dead limbs broke off, however, and were embedded in the old pine. Twelve years' growth covered them, and they remained hidden from view until my splitting revealed them. Two other wounds started promptly to heal and, with one exception, did so.

A year or two later some ants and borers began excavating their deadly' winding ways in the old pine. They probably started to work in one of the places injured by the falling tree. They must have liad some advantage, or else something must have happened to the nuthatches and chickadees that year, for, despite the vigilance of these birds, both the borers and the ants succeeded in establishing colonies that threatened injury and possibly death. 


\section{A THOUSAND-YEAR PINE}

Fortunately relief came. One day the chief surgeon of all the Southwestern pineries came along. This surgeon was the Texas woodpecker. He probably did not long explore the ridges and little furrows of the bark before he discovered the wound or heard these hidden insects working. After a brief examination, holding his ear to the bark for a moment to get the location of the tree's deadly foe beneath, he was ready to act. He made two successful operations. Not only did these require him to cut deeply into the old pine and take out the borers, but he may also liave liad to come back from time to time to dress the wounds by devouring the ant-colonies which may have persisted in taking possession of them. The wounds finally healed, and 


\section{A THOUSAND-IEAR PINE}

only the splitting of the affected parts revealed these records, all filled with pitch and preserved for nearly nine hundred years.

Following this, an even tenor marked his life for nearly three centuries. This quiet existence came to an end in the summer of 1301, when a stroke of lightning tore a limb out of his round top and badly shattered a shoulder. He had barely recovered from this injury when a violent wind tore off several of his arms. During the summer of 1348 he lost two of his largest arms. These were sound, and more than a foot in diameter at the points of breakage. As these were broken by a down-pressing weight or force, we may attribute the breaks to accumulations of snow. 


\section{A THOUSAND-YEAR PINE}

The oldest, largest portion of a tree is the short section immediately above the ground, and, as this lower section is the most exposed to accidents or to injuries from enemies, it generally bears evidence of having suffered the most. Within its scroll are usually found the most extensive and interesting autobiographical impressions.

It is doubtful if there is any portion of the earth upon which there are so many deadly struggles as upon the earth around the trunk of a tree. Upon this small arena there are battles fierce and wild; here nature is "red in tooth and claw." When a tree is small and tender, countless insects come to feed upon it. Birds come to it to devour these insects. Around the tree are daily ahmost merciless fights 


\section{A THOUSANI)-YEAR PINE}

for existence. These deatli-struggles occur not only in the daytime, but in the night. Mice, rats, and rabbits destroy millions of young trees. These bold animals often flay baby trees in the daylight, and while at their deadly feast many a time have they been surprised by hawks, and then they are at a banquet where they themselves are eaten. The owl, the faithful nightwatchman of trees, often swoops down at night, and as a result some little tree is splashed with the blood of the very animal that came to feed upon it. The lower section of Old Pine's trunk contained records which I found interesting. One of these in particular aroused my imagination. I was sawing off a section of this lower portion when the saw, with a buzz-z-z-z, suddenly 


\section{A THOUSAND-YEAR PINE}

jumped. 'The object struck was harder than the saw. I wondered what it could be, and, cutting the wood carefully away, laid bare a flint arrowhead. Close to this one I found another, and then with care I counted the rings of growth to find out the year that these had wounded Old Pine. The outer ring which these arrowheads had pierced was the six hundred and thirtieth, so that the year of this occurrence was 1486 .

Had an Indian bent his bow and shot at a bear that had stood at bay backed up against this tree? Or was there around this tree a battle among Indian tribes? Is it possible that at this place some Cliff-Dweller scouts encountered their advancing foe from the north and opened hostilities? It 


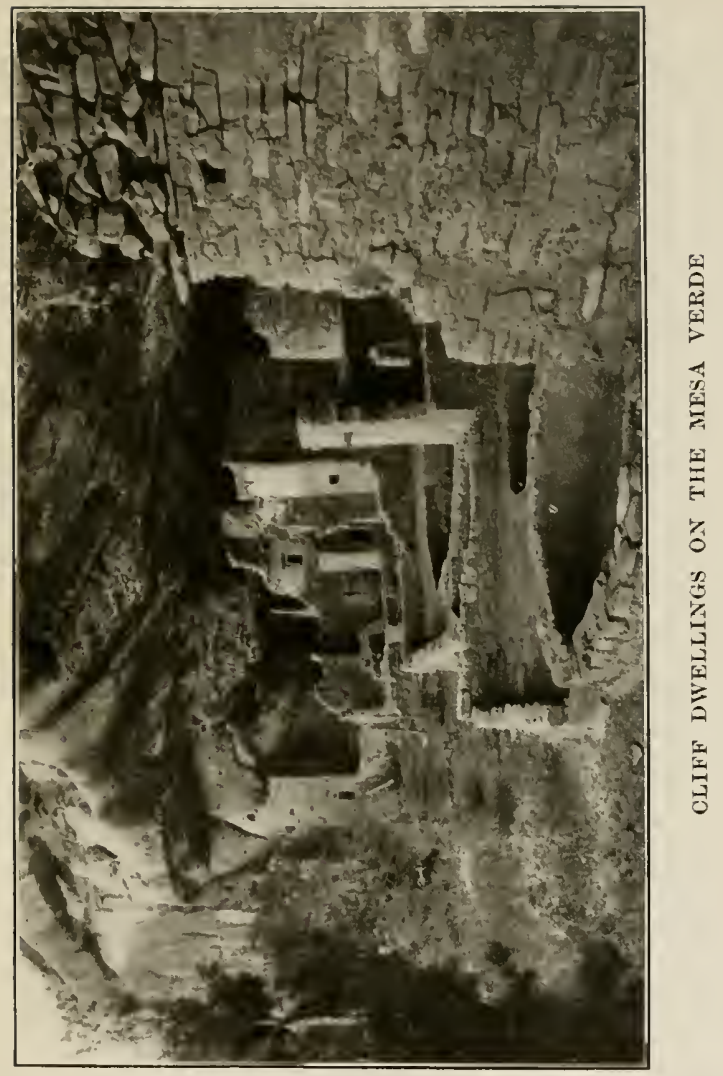





\section{A THOUSAND-YEAR PINE}

may be that around Old Pine was fought the battle that is said to have decided the fate of that mysterious race, the Cliff-Dwellers. The imagination insists on speculating with these two arrowheads, though they form a fascinating clue that leads us to no definite conclusion. But the fact remains that Old Pine was wounded by two Indian arrowheads some time during his six hundred and thirtieth summer.

The yeir that Columbus discovered America, Old Pine was a handsome giant with a round head held more than one hunchred feet above the earth. He was six hundred and thirty-six years old, and with the coming of the Spanish adventurers his lower trunk was given new events to record. The 


\section{A THOUSAND-YEAR PINE}

year 1540 was a particularly memorable one for him. This year brought the first horses and bearded men into the drama which was played around him. This year, for the first time, he felt the edge of steel and the tortures of fire. The old chronicles say that the Spanish explorers found the cliff-houses in the year 1540. I believe that during this year a Spanish exploring party may have camped beneath Old Pine and built a fire against his instep, and that some of the explorers hacked him with an axe. The old pine had distinct records of axe and fire markings during the year 1540. It was not common for the Indians of the West to burn or mutilate trees, and it was common for the Spaniards to do so, and as these hackings in the tree seemed to have 


\section{A THOUSAND-YEAR PINE}

been made with some edged tool sharper than any possessed by the Indians, it at least seems probable that they were made by the Spaniards. At any rate, from the year 1540 until the day of his death, Old Pine carried these scars on his instep.

As the average yearly growth of the old pine was about the same as in trees similarly situated at the present time, I suppose that climatic conditions in his early days must have been similar to the climatic conditions of to-day. His records indieate periods of even tenor of elimate, a year of extremely poor conditions, oceasionally a year crowned with a bountiful wood harvest. From 1540 to 1762 I found little of special interest. In 1762, however, the season was not regular. After the 


\section{A THOUSAND-YEAR PINE}

ring was well started, something, perhaps a cold wave, for a time checked his growth, and as a result the wood for that one year resembled two years' growth; yet the difference between this double or false ring and a regular one was easily detected. Old Pine's "hard times" experience seems to have been during the years 1804 and 1805. I think it probable that those were years of drought. During 1804 the layer of wood was the thinnest in his life, and for 1805 the only wood I could find was a layer which only partly covered the trunk of the tree, and this was exceedingly thin.

From time to time in the old pine's record, I came across what seemed to be indications of an earthquake shock; 


\section{A THOUSAND-YEAR PINE}

but late in 1811 or early in 1812, I think there is no doubt that he experienced a violent shock, for he made extensive records of it. This earthquake occurred after the sap had ceased to flow in 1811, and before it began to flow in the spring of 1812. In places the wood was checked and shattered. At one point, some distance from the ground, there was a bad horizontal break. Two big roots were broken in two, and that quarter of the tree which faced the cliffs had suffered from a rock bombardment. I suppose the violence of the quake displaced many rocks, and some of these, as they came bounding down the mountain-side, collided with Old Pine. One, of about five pounds' weight, struck him so violently in the side that it remained 


\section{A THOUSAND-YEAR PINE}

embedded there. After some years the wound was healed over, but this fragment remained in the tree until I released it.

During 1859 some one made an axemark on the old pine that may have been intended for a trail-blaze, and during the same year another fire badly burned and scarred his ankle. I wonder if some prospectors came this way in 1859 and made cainp by him.

Another record of man's visits to the tree was made in the summer of 1881, when I think a hunting or outing party may have camped near here and amused themselves by shooting at a mark on Old Pine's ankle. Several modern rifle-bullets were found embedded in the wood around or just be- 


\section{A THOUSAND-YEAR PINE}

neatlı a blaze which was made on the tree the same year in which the bullets had entered it. As both these marks were made during the year 1881 , it is at least possible that this year the old pine was used as the background for a target during a shooting contest.

While I was working over the old pine, a Frémont squirrel who lived near by used every day to stop in his busy harvesting of pine-cones to look on and scold me. As I watehed him placing his cones in a hole in the ground under the pine-needles, I often wondered if one of his buried cones would remain there uneaten, to germinate and expand ever green into the air, and become a noble giant to live as long and as useful a life as Old Pine. I found myself trying to picture the 


\section{A THOUSAND-YEAR PINE}

scenes in which this tree would stand when the birds came singing back from the Southland in the springtime of the year 3000 .

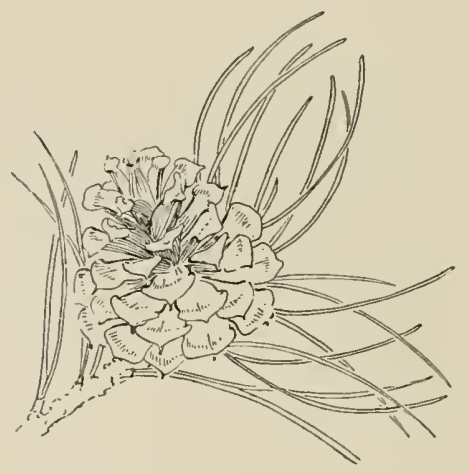


III

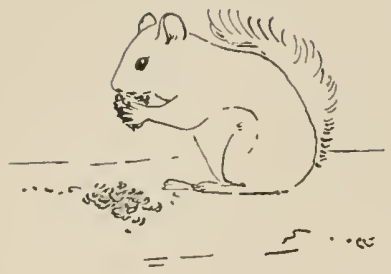





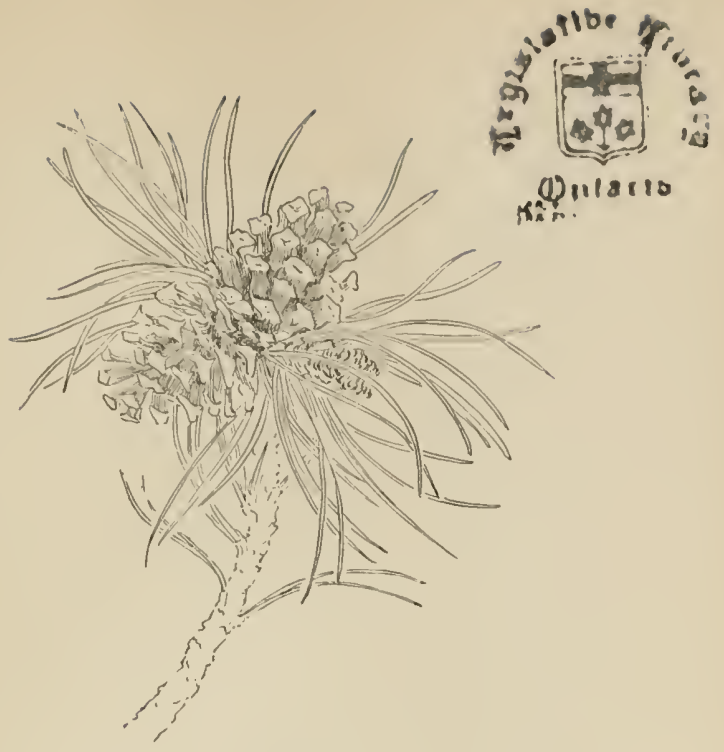

\section{III}

After I had finished my work of splitting, studying, and deeiphering the fragments of the old pine, I went to the sawmill and arranged for the men to come over that evening after I had departed, and burn every piece and vestige of the venerable old tree. I told them I should be gone by dark 


\section{A THOUSAND-YEAR PINE}

on a trip to the summit of Mesa Verde, where I was to visit a gnarled old cedar. Then I went back and piled into a pyramid every fragment of root and trunk and broken branch. Seating myself upon this pyramid, I spent some time that afternoon gazing through the autumn sun-glow at the hazy Mesa Verde, while my mind rebuilt and shifted the scenes of the long, long drama in which Old Pine had played his part and of which he bad given us but a few fragmentary records. I lingered there dreaming intil twilight. I thought of the cycles during which he had stood patient in his appointed place, and my imagination busied itself with the countless experiences that had been recorded, and the scenes and pageants he had 


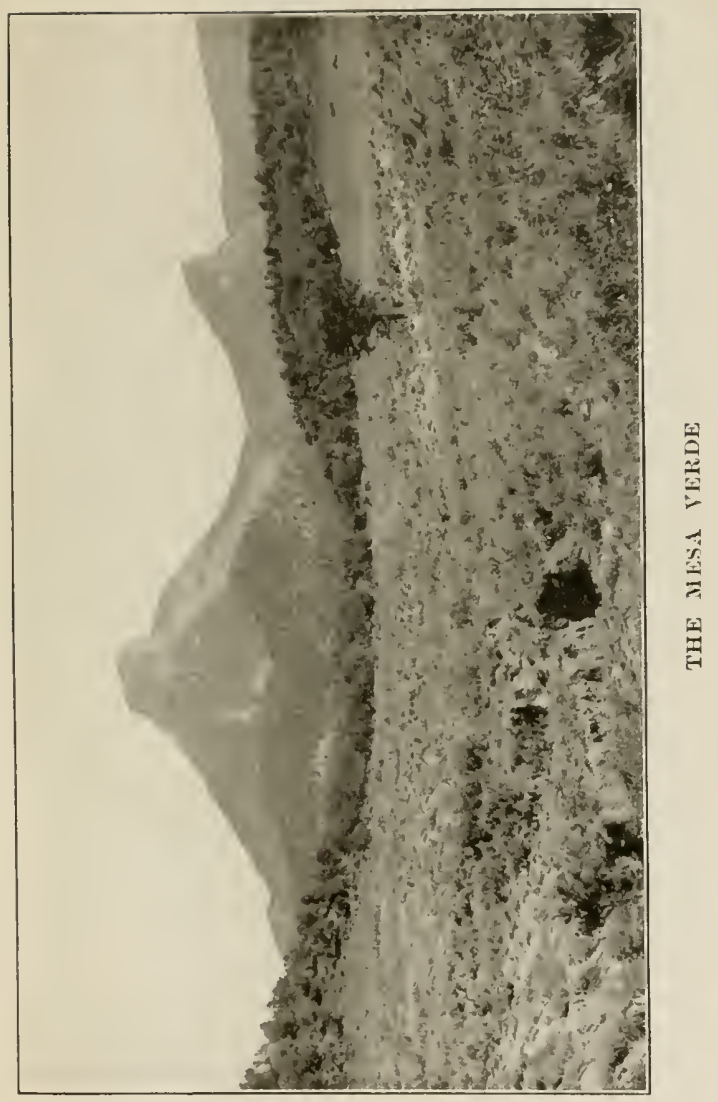





\section{A THOUSAND-YEAR PINE}

witnessed but of which he had made no record. I woudered if he had enjoyed the changing of seasons. I knew that he had often boomed or hymned in the storm or the breeze. Many a monumental robe of snowflowers had he worn. More than a thousand times he had beheld the earth burst into bloom anid happy songs of mating birds; hundreds of times in summer he had worn countless crystal rain-jewels in the sunlight of the breaking storm, while the brilliant rainbow came and vanished on the near-by mountain-side. Ten thousand times he had stood silent in the lonely light of the white and mystic miloon.

Twilight was fading into darkness when $I$ arose and started on my night 


\section{A THOUSAND-YEAR PINE}

journey for the summit of Mesa Verde.

When I arrived at the top of the Mesa,

I looked back and saw a pyramid of golden flame standing out in the darkness.

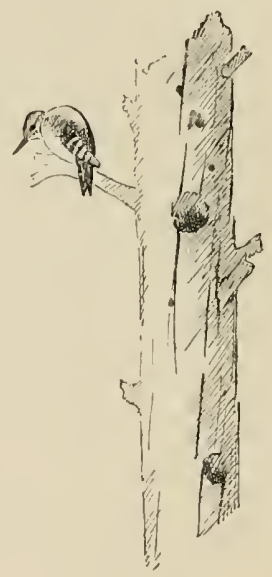





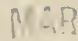

1

Che tiuluerside pregg

CAMBRIDGE - MASSACHUSETTS

$\mathrm{U} \cdot \mathrm{S} \cdot \mathrm{A}$ 



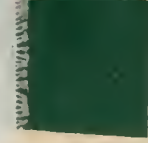

\section{PLEASE DO NOT REMOVE CARDS OR SLIPS FROM THIS POCKET}

\section{UNIVERSITY OF TORONTO LIBRARY}

QK 494

.5

P66M5
Mills, Enos Abijah

The story of a thousandyear pine

BioMed. 
1.1.

6. i6 3 s. 斩,

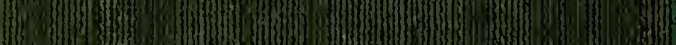

I0) (2) 8. 3.0.5. (3) W. (c. 15. 610: 15 (11) (18) gests 